\title{
THE PROBLEMS IN ACHIEVING SUSTAINABLE DEVELOPMENT IN THE TANNERY INDUSTRY IN REGARD TO SEWAGE SLUDGE MANAGEMENT
}

\author{
January Bień', Piotr Celary' ${ }^{1}$, Katarzyna Wystalska $^{1}$ \\ 1 Częstochowa University of Technology, Faculty of Infrastructure and Environment, \\ Institute of Environmental Engineering, Brzeźnicka 60a, 42-200 Częstochowa, Poland, e-mails: \\ pcelary@is.pcz.czest.pl, kawyst@is.pcz.czest.pl
}

Received: 2017.08.30

Accepted: 2017.10.01

Published: 2017.11.01

\begin{abstract}
The paper discusses the issue of tannery sewage sludge management as one of the barriers in reaching sustainable development in the tanning industry. The Authors present the main characteristics, and its origins, of tannery sludge limiting the possibilities of their treatment and review the proposed solutions found in literature. The paper focuses on identifying the strong and weak points of the most commonly used methods used for sewage sludge treatment as well as presents some novel approaches which remain at laboratory stage.
\end{abstract}

Keywords: sustainable development, tannery industry, sewage sludge, chromium

\section{INTRODUCTION}

According to Global Footprint Network, a non-profit organization that calculates human demands on the planet's ecosystems, as of 2013, the world's population would need an estimated equivalent of 1.7 Earths to support its needs for renewable natural resources. As it turns out Poland's consumption per capita relative to what the country's biosphere can regenerate equals to 4.3 gha (global hectares) while its capacity to renew the resources demanded from its ecosystems is only 2.0 gha resulting in a $53.49 \%$ deficit equal to 2.3 gha (Global Footprint Network). This only strengthens the need for the implementation of sustainable development in the Polish industry for the sake of future generations. However some industries, due to technology specific operations, are still struggling in achieving sustainable development, one of them being the tannery industry.

\section{THE TANNERY INDUSTRY}

The tannery industry is not only one of the oldest ones, with great traditions in the world but also, or rather most importantly it is an integral part of the logistic chain of processing byproducts from the meat industry making it vital for the economy of many developing countries (Kolomaznik et al., 2008; Lofrano et al., 2013; Jiang et al., 2016; Wu et al., 2017).

The operations carried out by tanneries come down mainly to the processing of raw hides in order to obtain finished leather that can be used for the production of the well-known pieces of wardrobe, furniture as well as some household items (Bartkiewicz, 2006).

Bartkiewicz (2006) divides the sub-processes required to make finished leather into the following 3 major groups:

- beamhouse operations;

- tanyard processes;

- finishing.

The second one being the most important and troublesome. It is the tannage operation that makes the leather resistant, durable and immune to, among others, rotting or drying out (Bartkiewicz, 2006). The discovery of chromium tanning (Wet-Blue technology) lead to a revolution in the tannery industry and successful replacement of 
vegetable tannins as tanning agents allowing for faster processing and higher quality of leather, it did however result in other problems (Sreeram and Ramasami, 2003; Bartkiewicz, 2006).

While the properties of chromium tanned leather are second to none the process itself is characterised by low efficiency manifested by $30-60 \%$ of used chromium salts, acting as tanning agents, ending up in the generated wastewater (Kolomaznik et al., 2008; Fongsatikul et al., 2011; Kilic et al., 2011; Sundarapandiyanet al.; 2011). Even more so, the processing of $1 \mathrm{Mg}$ of raw hides results in only $150-250 \mathrm{~kg}$ of finished leather (Kilicet al., 2011; Kavouraset al., 2015).

The above is one of the many reasons why the tannery industry is regarded as one of the most polluting industries in the world and is assumed to be responsible for about $40 \%$ of global chromium pollution (Cassano et al., 2001; Kolomaznik et al., 2008; Jiang et al., 2016; Wu et al., 2017).

The mentioned drawbacks of using chromium salts as tanning agents also impede the attempts in making the tanning process a sustainable one and in combination with the dangers to the environment posed by their use drove the process of extensive research focused on finding alternatives among compounds such as aluminium (III) salts, iron (III) salts, sodium silicates, titanium (III) sulfates, potassium titanyl oxalate, zirconium (IV) salts, bifunctional aldehydes (such as glutaraldehyde) and many others (Sreeram and Ramasami, 2003).

However none of the above allowed for producing leather of similar elasticity, softness, dura- bility, heat resistance and other properties of that obtained through chromium tanning, in addition some of the investigated tanning agents are not economically viable (Sreeram and Ramasami, 2003; Zouboulis et al., 2012; Zhang et al., 2016).

Until an alternative to chromium salts as tanning agents can be found or technical advancements allowing for improving the efficiency of the Wet-Blue technology are made, in order to make the tanning process as close to sustainable as possible it is necessary to develop and implement methods transforming currently produced tannery waste such as sewage sludge into products of the highest possible market value.

\section{TANNERY SLUDGE MANAGEMENT FOR SUSTAINABLE DEVELOPMENT}

Although the quantity and characteristics of the generated tannery sewage sludge varies greatly depending on the tanning technology, raw materials, skin type production profile as well as wastewater treatment technology and so on it is assumed that on average theprocessing of $1 \mathrm{Mg}$ of raw hides results in the generation of 100-150 kg of sewage sludge (Kanagaraj et al., 2006; Kavouras et al., 2015). This variety is also reflected in the sewage sludge heavy metal content reported in literature (Table 1). This pollution load makes it difficult or even impossible to imploy many biological treatment methods usually associated with sewage sludge management. This limitation will however apply to sew-

Table 1. Parametry osadów ściekowych z przemysłu garbarskiego na podstawie danych literaturowych

\begin{tabular}{|c|c|c|c|c|c|}
\hline \multirow{2}{*}{ Reference } & Chromium & Cadmium & Nickel & Zinc & Lead \\
\hline & \multicolumn{5}{|c|}{$\mathrm{mg} / \mathrm{kg}$ drymatter } \\
\hline Alibardi and Cossu, 2016 & 44900.00 & - & 26.00 & 1120.00 & - \\
\hline Allue et al., 2014 & 6030.00 & 52.80 & 20.00 & 645.00 & 70.00 \\
\hline Chuan and Liu, 1996 & 17000.00 & - & - & 110.00 & 49.00 \\
\hline Fang and Zhou, 2007 & 14180.00 & - & - & 126.00 & 87.00 \\
\hline Fongsatitkul et al., 2011 & $474000.00 \pm 15700.00$ & - & - & - & - \\
\hline Ghosh et al., 2013 & 14212.00 & $<0.01$ & 272.00 & 241.00 & 58.20 \\
\hline Gupta and Sinha, 2007 & $7489.76 \pm 203.00$ & $95.10 \pm 1.25$ & $219.16 \pm 21.73$ & $340.69 \pm 11.10$ & $143.43 \pm 8.72$ \\
\hline Juelet al., 2017 & $19299.00 \pm 6303.00$ & $<0.01$ & $139.50 \pm 1.91$ & $250.60 \pm 68.00$ & $63.80 \pm 5.60$ \\
\hline Kavouras et al., 2015 & 86000.00 & - & - & - & - \\
\hline Killicet al., 2011 & 8041.00 & 18.50 & 34.50 & 1300.00 & 98.50 \\
\hline Li et al., 2005 & 11320.00 & - & - & - & - \\
\hline Lopez-Luna et al., 2009 & 65016.00 & - & - & - & - \\
\hline Tang et al., 2013 & 17140.00 & 10.00 & - & 260.00 & 1610.00 \\
\hline Trebien et al., 2011 & 8869.00 & - & - & - & - \\
\hline Montanes et al., 2014 & $7903.00 \pm 58.00$ & - & - & - & - \\
\hline Wang et al., 2007 & $35000.00 \pm 1360.00$ & - & - & - & - \\
\hline
\end{tabular}


age sludge generated during treatment of wastewater coming either from the entire tannery or from the tannage operations alone at tannieries carrying out the tanning process using the WetBlue technology (chromium tanning). In the first case the sewage sludge will be characterized by a chromium content hampering biological treatment processes or in the best case the result of such treatment will be a product (e.g. compost) of very limited use. In the second scenario the precipitated sewage sludge will have miniscule nutrient content making it unsuitable for biological treatment as it will not improve any properties of the feedstock.

However the above will apply to most cases since it is estimated that around $80-90 \%$ of tanneries in the world use chromium salts as tanning agents (Lopez-Luna et al., 2009; Montanes et al., 2014; Bacardit et al., 2015).

As shown in research of Barajas-Aceves (2014) tannery sewage sludge and tannery waste in general can't be directly used in soils due to the possibility of contaminating groundwater, water reservoirs, destabilization of nitrogen and carbon mineralization, hampering dehydrogenase activity in the soil as well as promoting its erosion.

Numerous examples of composting of tannery sewage sludge can be found in literature. However in most cases the sewage sludge used in these research is characterised by a chromium content of no more than $1000 \mathrm{mg} / \mathrm{kg}$ being which is extremely low considering its origin.

Haroun et al. $(2007 ; 2009)$ composted tannery sludge with a chromium content of $350-500$ $\mathrm{mg} / \mathrm{kg}$ mixed with sawdust, chicken droppings and rice bran $(100 \mathrm{~kg}, 50 \mathrm{~kg}, 30 \mathrm{~kg}$ and $20 \mathrm{~kg}$ respectively) in piles turned manually every 10 days. After 60 days the obtained compost was characterized by a chromium content of $100 \mathrm{mg} /$ $\mathrm{kg}$ allowing for agricultural use in the country of the Authors. However as it was previously stated, the used tannery sludge had an uncommonly low chromium content to begin with, in addition the Authors did not define the tanning agents used at the tannery from which the sewage sludge originated making it a possibility of it being a rare example of non-chromium tanning process. (Haroun et al., 2007; Haroun et al., 2009). Another example of composting of tannery sludge can be found in the research carried out by Li et al. (2005) who processed sewage sludge characterised by a chromium content of $11320 \mathrm{mg} / \mathrm{kg}$. By treating a mixture of sewage sludge and straw at a ratio of 3:5 the Authors obtained compost with a chromium content of $10360 \mathrm{mg} / \mathrm{kg}$ which, as underlined by the Authors themselves, in order to meet their national criteria regarding the content of chromium in rice, limited its use so the introduced load of chromium did not exceed 350mg of chromium per $\mathrm{kg}$ of soil.

Different restrictions in regard to use of compost obtained from tannery sludge were found by Araujo et al. (2015). The long-term use of compost (chromium content of $1943 \mathrm{mg} / \mathrm{kg}$ ) at a dose of $10 \mathrm{Mg} / \mathrm{ha}$ resulting from the processing of tannery sludge, sugarcane straw and cow manure at a ratio of 1:3:1, negatively affected enzyme activity and resulted in reduced microorganism biomass in the soil.

Regardless of the possibility of carrying out the composting process numerous research show that the obtained final product due to its high content of chromium will have little to no use which makes this process not a viable choice.

Another biological method typically associated with sewage sludge treatment is anaerobic digestion. However, just like in the case of composting, high heavy metal content questions its potential usefulness in regard to tannery sludge which is reflected by very few examples in literature. Even more so anaerobic digestion microorganisms seem to be more prone to the toxic effects of chromium $3+$ which is the dominant form of chromium in tannery sludge, while for most organisms, including humans, it's the hexavalent chromium which is considered more hazardous (Janosz-Rajczyk et al., 2006).

As noted by Appels et al. (2008) trivalent and hexavalent chromium show a high inhibitory effect on the anaerobic digestion process at concentrations of 180 and $200 \mathrm{mg} / \mathrm{dm}^{3}$ respectively. Priebe et al. (2016) reports even lower LD50 values of 160 and $80 \mathrm{mg} / \mathrm{dm}^{3}$ respectively. Moreover as pointed out by Chen et al. (2008) the sensitivity to certain metals for acidogenesis and methanogenesis forms the following orders $\mathrm{Cu}>\mathrm{Zn}>\mathrm{Cr}>\mathrm{Cd}>\mathrm{Ni}>\mathrm{Pband}$ $\mathrm{Cd}>\mathrm{Cu}>\mathrm{Cr}>\mathrm{Zn}>\mathrm{Pb}>\mathrm{Ni}$ respectively. The relative toxicity being $\mathrm{Cr}>\mathrm{Ni}>\mathrm{Cu}>\mathrm{Zn}$ (Chen et al., 2008). Even moreso many kinds of heavy metals cause synergistic toxicity effects, some of the combinations being $\mathrm{Cr}-\mathrm{Cd}, \mathrm{Cr}-\mathrm{Pb}, \mathrm{Cr}-\mathrm{Cd}-\mathrm{Pb}$ (Chen et al., 2008).

Taking this into account it seems that anaerobic digestion at current technological state-of-art also seems to be the wrong approach in managing tannery sewage sludge. 
The problem is so grave that some researchers embrace the idea of sustainable landfilling (Widomski et al., 2017) and cast aside the attempts to create a commercial product from tannery sewage sludge (Alibardi and Cossu; 2016).

Alibardi and Cossu (2016) proposed pretreatment of tannery sludge for sustainable landfilling by aerobic stabilisation of a mixture of primary and waste activated sludge (chromium content of $44900 \mathrm{mg} / \mathrm{kg}$ ) with compost. The mixture underwent aerobic stabilisation in a reactor with a continuous forced aeration for 80 days. The treated material was turned manually every 3-4 days. After stabilisation the material was mechanically compacted and dried in order to reduce its mass and volume. In the Authors view such an approach allowed for sustainable landfilling of the treated material as well as minimisation of potential environmental impacts of the landfilled material and extended the life time of the landfill. While the reduction in mass and volume is desirable the amount of resource and energy needed for the numerous processing steps which still result in landfilling seem to be an ad hoc solution which doesn't bring the tannery industry any closer to sustainable development.

Due to the large amounts of chromium in tannery sludge from a sustainable development perspective it only seems natural to investigate the possibility of its extraction and reuse.

Bareen and Khilji (2008) made such an attempt using Typhaangustifoli L. a means of extracting chromium from specially made water solutions of tannery sludge $(0 \%, 30 \%$ and $60 \%)$. The research resulted in a maximum chromium extraction of $42 \%$ after a period of 90 days for the $30 \%$ tannery sludge solution. The Authors estimated that for the used sludge the time needed for complete chromium extraction should oscillate around 270 days (Bareen and Khilji, 2008). However yet again the concentration of chromium turned out to be a limiting factor, for solutions of $60 \%$ and more within a week the plants started to wither, after which chlorosis and decay was observed (Bareen and Khilji, 2008).

A different way of chromium extraction using microorganisms was proposed by Zhou et al. (2005). By using the TS6 strand of Acidithiobacillusthiooxidans the Authors achieved a chromium recovery efficiency of $96 \%$ from acidified sewage sludge in a period of 6 to 8 days. While this method is not restricted by the initial chromium content of the treated sludge it hampered by the presence of organic matter which disrupts the life cycle of the mentioned microorganism. Fang and Zhou (2006) reported that as little as $150 \mathrm{mg} / \mathrm{dm}^{3}$ of dissolved organic carbon leads to a $70 \%$ decrease in sulfur oxidation activity of the mentioned microorganisms successfully hampering the extraction process. In addition the described approach doesn't raise the issues of transforming the extracted chromium into a useable form as well as the cost of neutralisation and management of the acidified chrome-free sludge (Zhou et al., 2005).

The only known attempt of a full environment impact and cost assessment in regard to chrome extraction and its recycling in the tannery industry in the form of a LCA (Life Cycle Assessment) known to the Authors is the work of Kilic et al. (2011).

The performed research showed that it is possible to chemically extract as much as $64 \%$ of chromium from tannery sludge however due to the numerous chemicals involved and the byproducts of the process it is only ecologically viable for tannery sewage sludge with a chromium content of no less than $161000 \mathrm{mg} / \mathrm{kg}$ virtually making the process inapplicable since in most cases tannery sewage sludge doesn't come near such concentration as can be seen in Table 1 (Kilic et al., 2011). Moreover the Authors did not take into account the cost of managing the postextraction sludge which would still bear a significant load of chromium (a minimum of 57960 $\mathrm{mg} / \mathrm{kg}$ ) and do to its acidification (a critical step in the chemical extraction process) would pose a much greater to the environment than "normal" tannery sewage sludge with the same chromium content (Kilic et al., 2011). An additional problem is the obtained chromium solution, which as stated by many Authors is of low quality and numerous impurities (Cassanoet al., 2001; Basegioet al., 2009; Kilicet al., 2011).

A very promising approach in solving the issue of tannery sludge management seems to be of solidification which incorporates the use of numerous binding agents such as cement. The possibility of solidifying tannery sewage sludge (chromium content of $474000 \mathrm{mg} / \mathrm{kg}$ ) using rice husk ash and cement was investigated by Fongsatitkul et al. (2011). The solidified samples compressive strength was inversely proportional to the share of the sewage sludge in the composite. The highest compressive strength after 28 days of curing was noted for a mixture containing around $17 \%$ 
of tannery sludge, $16 \%$ of rice husk ash and almost $67 \%$ of cement (Fongsatitkul et al., 2011). The highest investigated share of tannery sludge in the solidified material was $44.5 \%$ which required the same amount of cement, and rice husk ash addition of $11 \%$. The obtained composite was characterised by compressive strength below $15 \mathrm{MPa}$ and more importantly it did not meet the Authors national heavy metal lixiviation criteria (Fongsatitkulet al., 2011).

Other researchers like Filibeli et al. (2000) as well as Montanes et al. (2014) also noted that the effectiveness of some solidification methods is limited by the high chromium content of tannery sewage sludge which not only requires the use of significant amounts of cement, which is one the most expensive additives in concrete, but also can prevent its solidification with other waste such as fly ash. The characteristics of tannery sewage sludge can also prevent the obtained solidified material to be used in construction reducing its advantages to environmental safety and lower landfilling cost.

The constantly expanding incineration infrastructure mainly to meet the needs of municipal waste treatment combined with chromium's relatively low volatility in high temperatures makes thermal treatment of waste such as tannery sewage sludge an option worth investigating (Jiang et al., 2010; Tang et al., 2013).

However as reported by many researchers the incineration of tannery sewage sludge involves the risk of oxidising trivalent chromium into the cancerogenic hexavalent form of this metal (Tang et al., 2008; Jiang et al., 2010; Tang et al., 2013; Mao et al., 2016).

As pointed out by Kavouras et al. (2015) tannery sewage sludge thermal treatment in temperatures as low as $500^{\circ} \mathrm{C}$ leads to total oxidation of chromium present. However in their research the Authors noted that in higher temperatures slow but steady reduction of previously oxidised chromium also takes place, reaching close to $32 \%$ at $1200^{\circ} \mathrm{C}$ (Kavouras et al., 2015)

A lot of research carried out in Asia focused on the possibility of reducing chromium oxidation and heavy metal volatility in general during incineration of sewage sludge via various additives, some them being hydroxyapatite, phosphoric acid and others (Tang et al, 2008; Jiang et al., 2010; Tang et al., 2013; Mao et al., 2016).

However other researchers lean to the idea of simply using different thermal treatment meth- ods involving an atmosphere free or with limited amounts of oxygen such as pyrolysis which would possibly also resolve the problem of the ash generated during incineration (Caballero et al., 1998; Kavouras et al., 2015; Ma et al., 2015).

Pyrolysis seems to be a promising approach and in the future could possibly be the go-to method of treating tannery sludge mainly due to the elimination of chromium oxidation however research conducted by Sivaprakash et al. (2016),albeit for leather buffing dust, showed that the resulting biochar, just like incineration ash, has a high content of heavy metals which will significantly limit its use and requires additional processes in order to be safely utilized. Sivaprakash et al. (2016) proposed the use of iron nanoparticle amended biochar as material for the production of lightweight concrete blocks. The issue of tannery sludge biochar can be somewhat found in the research of Ma et al. (2015), who didn't investigate the danger resulting from high heavy metal content and assumed its safety by referencing research in which the treated sludge was characterised by miniscule quantities of chromium of $23.86 \mathrm{mg} / \mathrm{kg}$. This makes the possibility of incorporating pyrolysis as the preferred treatment method as an issue open to debate at least until more research regarding the safety of the resulting biochar is published.

One of the last thermal treatment methods with a well-documented effectiveness in treating waste characterised by high content of heavy metals is vitrification (Malki et al., 2005; Karamanov et al., 2007; Dunnett et al., 2012).

Although chromium immobilisation in the vitrification process has been confirmed in numerous research there are very few examples of its use for tannery waste management (Meegoda et al., 1999; Meegoda et al., 2000; Basegio et al. 2009; Lazau and Vancea, 2014). To date there is only few research regarding vitrification of tannery sewage sludge one them being the work of Sobiecka and Szymański (2014) who through vitrification of tannery sewage sludge and municipal solid waste incinerator asha product of negligible heavy metal leaching and hardness that allows to assume it could find application in the construction industry.

Another example could be the research carried out by Bień et al. (2013) investigating the possibility of using dolomite flotation waste from the zinc-lead and the copper industry as an additive in the vitrification process of tannery sludge 
with waste foundry sands. The research showed promising results in regard to heavy metal immobilisation, especially when appropriate amounts of zinc-lead post-flotation waste was used.

Based on the findings of Bien et al. (2013), Celary and Sobik-Szołtysek (2014) carried out research focused on optimising tannery sewage sludge vitrification and allowed them to obtain an uniform, homogeneous and vitreous product with high heavy metal incorporation level as well as reduced metal leaching properties and hardness allowing for its potential future use in the construction industry.

However all of the above mentioned research have yet to confirm a direct application of the obtained products and due to the energy-intensive character of the vitrification process still require a careful cost assessment and installation design allowing to reduce costs for example via heat energy recovery.

\section{CONCLUSION}

Over the years many varying approaches for sustainable tannery sludge management have been proposed, however none of them proved to be the ideal and final solution of this very important issue. It seems reasonable to assume that due to the fact that no treatment process is flaw free in order to reach a sustainable solution it is necessary to combine different technologies creating a technology consisting of subsequent processes allowing for maximum recuperation of resources and if possible eliminating the need of landfilling of any by-products resulting from their employment. However at current state-of-art it seems that due to technological limitations sustainable tanning will remain unobtainable for quite some time.

\section{Acknowledgement}

This research was supported by BS/PB-401/301/11.

\section{REFERENCES}

1. Alibardi L., Cossu R., 2016, Pre-treatment of tannery sludge for sustainable landfilling, Waste Management, vol. 52, p. 202-211.

2. Allue J., Moya Garces A., Bech J., Barcelo J. POSCHENRIEDER C., 2014, Fractionation of chromium in tannery sludge-amended soil and its availability to fenugreek plants, Journal of Soils and Sediments, vol. 14, p. 697-702.

3. Appels L., Baeyens J., Degreve J., Dewil R., 2008, Principles and potential of the anaerobic digestion of waste-activated sludge, Progress in Energy and Combustion Science, vol. 34, p. 755-781.

4. Araujo A.S.F., Miranda A.R.L., Oliveira M.L.J., Santos V.M., Nunes L.A.P.L., Melo W.J., 2015, Soil microbial properties after 5 years of consecutive amendment with composted tannery sludge, Environmental Monitoring Assessment, vol. 187, p. 41-53.

5. Bacardit A., Baquero G., Sorolla S., Olle L., 2015, Evaluation of a new sustainable continuous system for processing bovine leather, Journal of Cleaner Production, vol. 101, p. 197-204.

6. Barajas-Aceves M., Rios Berber J.D., Oropeza Mota J.L., Rodriguez Vazquez R., 2014, Assessment of Tannery Waste in Semi-arid Soils Under a Simulated Rainfall System, Soil and Sediment Contamination: An International Journal, vol. 23, no 8, p. 954-964.

7. Bareen F., Khilji S., 2008, Bioaccumulation of metals from tannery sludge by Typhaangustifolia L., African Journal of Biotechnology, vol. 7, no 18, p. 3314-3320.

8. Bartkiewicz B., Oczyszczanie ścieków przemysłowych, Wydawnictwo naukowe PWN, Warszawa 2006.

9. Basegio T., Beck Leao A.P., Bernardes A.M., Bergmann C.P., 2009, Vitrification: Analternative to minimizeenvironmentalimpactcaused by leatherindustrywastes, Journal of Hazardous Materials, vol. 165, p. 604-611.

10. Bień J.B., Celary P., Morzyk B., Sobik-Szołtysek J., Wystalska K., 2013, Effect of additives on heavy metal immobilizationduringvitrification of tannerysewagesludge, Environment Protection Engineering, vol. 39, no 2, p. 33-40.

11. Caballero J.A., Font R., Esperanza M.M., 1998, Kinetics of the thermaldecomposition of tannery waste, Journal of Analytical and Applied Pyrolysis, vol. 47, p. 165-181.

12. Cassano A., Molinari R., Romano M., Drioli E., 2001, Treatment of aqueouseffluents of the leatherindustry by membraneprocesses A review, Journal of Membrane Science, vol. 181, p. 111-126.

13. Celary P., Sobik-Szołtysek J., 2014, Vitrification as analternative to landfilling of tannerysewagesludge, Waste Management, vol. 34, 2520-2527.

14. Chen Y., Cheng J.J., Creamer K.S., 2008, Inhibition of anaerobicdigestionprocess: a review, Bioresource Technology, vol. 99, no 10, p. 4044-4064.

15. Chuan M.C., Liu J.C., 1996, ReleaseBehaviour of chromium from tannerysludge, Water Resource, 
vol. 30, no 4, p. 932-938.

16. Dunnett B.F., Gribble N.R., Short R., Turner E., 2012, Vitrification of high moiybdenum waste, Glass Technolology: EuropeanJournal of Glass Science Technology A, vol. 53, no 4, p. 166-171.

17. Fang D., Zhou L-X., 2006, Effect of sludgedissolvedorganicmatter on oxidation of ferrous iron and sulfur by Acidithiobacillusferroxidans and Acidithi obacillusthiooxidans, Water, Air and SoilPollution, vol. 171, p. 81-94

18. Fang D., Zhou L-X., 2007, Enhanced Cr bioleachinge effciency from tannerysludge with coinoculation of Acidithiobacillusthiooxidans TS6 and Brettanomyces B65 in anair-lift reactor, Chemosphere, vol. 69, p. 303-310.

19. FIlibeli A., Buyukkamaci N., Senol H., 2000, Solidification of tannerywastes, Resources, Conservation and Recycling, vol. 29, p. 251-261.

20. Fongsatitkul P., Elefsiniotis P., Kitkaew D., Rungsipanororn C., 2011, Use of Rice Husk Ash as anAdmixture to RemoveChromium from a Tannery Waste, WaterAirSoilPollution, vol. 220, p. 81-88.

21. Ghosh S., Mukherjee S., Alhamdan A., Reddy K., 2013, Efficacy of finegrainedsoil as landfillinermaterial for containment of chrome tannerysludge, Geotechnical and Geological Engineering,vol. 31, p. 493-500.

22. Global Footprint Network, http://www.footprintnetwork.org (03.05.2017r.).

23. Gupta A.K., Sinha S., 2007, Phytoextraction capacity of the plants growing on tannery sludge dumping sites, Bioresource Technology, vol. 98, p. 1788-1794.

24. Haroun M., Idris A., Omar S.R.S, 2007, A study of heavy metals and their fate in the composting of tannery sludge, Waste Management, vol. 27, p. 1541-1550.

25. Haroun M., Idris A., Omar S.R.S, 2009, Analysis of heavy metals during composting of the tannery sludge using physicochemical and spectroscopic techniques, Journal of Hazardous Materials, vol. 165, p. 111-119.

26. Janosz-Rajczyk M., Dąbrowska L., Rosińska A., Płoszaj J., Zakrzewska E., Zmianyilościowojakościowe PCB, WWA, imetaliciężkich w kondyc jonowanychosadachściekowychstabilizowanychb iochemicznie, WydawnictwoPolitechnikiCzęstoch owskiej, Częstochowa 2006.

27. Jiang H., Liu J., Han W., 2016, The status and developments of leather solid waste treatment: A mini-review, Waste Management \& Research, vol. 34, no 5, p. 399-408.

28. Jiang X-G., Li C-Y., Fei Z-W., Chi Y., Yan J-H., 2010, Combustion characteristics of tannery sludge and volatilization of heavy metals in combustion,
Journal of Zhejiang University-Science A (Applied Physics \& Engineering), Vol. 11, No 7, P. 530-537.

29. Juel M.A.I., Mizan A., Ahmed T., 2017, Sustainable use of tannery sludge in brick manufacturing in Bangladesh, Waste Management, vol. 60, 259-269.

30. Kanagaraj J., Velappan K.C., Chandra Babu N.K., Sadulla S., 2006, Solid wastes generation in the leather industry and its utilization for cleaner environment - a review, Journal of Scientific and Industrial Research, vol. 65, p. 541-548.

31. Karamanov A., Aloisi M., Pelino M., 2007, Vitrification of copper flotation waste, Journal of Hazardous Materials, vol. 140, p. 333-339.

32. Kavouras P., Pantazopoulou E., Varitis S., Vourlias G., Chrissa K., Dimitrakopulos G.P., Mitrakas M., Zouboulis A.I., Karaostas T., Xenidis A., 2015, Incineration of tannery sludge under oxic and anoxic conditions: study of chromium speciation, Journal of Hazardous Materials, vol. 283, p. 672-679.

33. Kilic E., Puig R., Baquero G., Font J., Colak S., Celak D., Gurler D., 2011, Environmental optimization of chromium recovery from tannery sludge using a life cycle assessment approach, Journal of Hazardous Materials, vol. 192, p. 393-401.

34. Kolomaznik K., Adamek M.,Andel I.,Uhlirova M., 2008, Leather waste - Potential threat to human health, and a new technology of its treatment, Journal of Hazardous Materials, vol. 160, p. 514-520.

35. Lazau I., Vancea C., 2014, New vitreous matrix for chromium waste immobilization, Central European Journal of Chemistry, vol. 12, no 7, p. 763-768.

36. Li G-J., Zhang C., Zhan J., Wang F., 2005, Chrome sludge compost - effect on crops and soils, Journal of the Society of Leather Technologists and Chemists, vol. 90, p. 10-13.

37. Lofrano G., Meric S., Zengin G.E., Orhon D., 2013, Chemical and biological treatment technologies for leather tannery chemicals and wastewaters: A review, Science of the Total Environment, vol. 461-462, p. 265-281.

38. Lopez-Luna J., Gonzalez-Chavez M.C., EsparzaGarcia F.J., Rodriguez-Vazquez R., 2009, Toxicity assessment of soil amended with tannery sludge, trivalent chromium and hexavalent chromium using wheat, oat and sorghum plants, Journal of Hazardous Materials, vol. 163, p. 829-834.

39. Malki M., Echegut P., Bessada C., Nuta I., Constantinescu M., Anghel E. M., Piper R., Olteanu M., 2005, Structure and properties of glasses obtained by recycling of secondary lead from acid battery plants, Glass Technology, vol. 46, no 4, p. 305-310.

40. Mao L., Deng N., Liu L., Cui H., Zhang W., 2016, Inhibition of $\mathrm{Cr}$ (III) oxidation during thermal treatment of simulated tannery sludge: the role of phosphate, Chemical Engineering Journal, vol. 294, p. 1-8. 
41. Meegoda J.N., Kamolpornwijit W., Vaccari D.A., Ezeldin A.S., Noval B.A., Mueller R.T., Santora S., Remediation of chromium-contaminated soils: benchscale investigation, 1999, Practice Periodical of Hazardous, Toxic, and Radioactive Waste Management, vol. 3, no 3, p. 124-131.

42. Meegoda J.N., Partymiller K., Richards M.K., Kamolpornwijit W., Librizzi W., Tate T., Noval B.A., Mueller R.T., Santora S., 2000, Remediation of chromium contaminated soils: Pilot-scale investigation, Practice Periodical of Hazardous, Toxic, and Radioactive Waste Management, vol. 4, no 1, p. 7-15.

43. Montanes M.T., Sanchez-Tovar R., Roux M.S., 2014, The effectiveness of the stabilization/ solidification process on the leachability and toxicity of the tannery sludge chromium, Journal of Environmental Management, vol. 143, p. 71-79.

44. Sivaprakash K., Maharaja P., Pavithra S., Boopathy R., Sekaran G., 2016, Preparation of lightweight constructional materials from chrome containing buffing dust solid waste generated in leather industry, Journal of Material Cycles and Waste Management, DOI 10.1007/s10163-016-0494-z

45. Sobiecka E.,Szymański Ł., 2014, Thermal plasma vitrification process as an effective technology for fly ash and chromium-rich sewage sludge utilization, Journal of Chemical Technology and Biotechnology, vol. 89, p. 1115-1117.

46. Sreeram K.J., Ramasami T., 2003, Sustaining tanning process through conservation, recovery and better utilization of chromium, Resources, Conservation and Recycling, vol. 38, 185-212.

47. Sundarapandiyan S., Brutto P.E., Siddhartha G., Ramesh R., Ramanaiah B., Saravanan P., Mandal A.B., 2011, Enhancement of chromium uptake in tanning using oxazolidine, Journal of Hazardous Materials, vol. 190, p. 802-809.
48. Tang P., Zhao Y.C., Chen D.Z., Xia F.Y., 2008, Volatility of heavy metals during incineration of tannery sludge in the presence of chlorides and phosphoric acid, Waste Management \& Research, vol. 26, p. 369-376.

49. Tang P., Zhao Y.C., Xie Z., 2013, Effects of hydroxyapatite addition on heavy metal volatility during tannery sludge incineration, Environmental Science Polution Research, vol. 20, p. 4405-4413.

50. Trebien D.O.P., Bortolon L., Tedesco M.J., Bissani C.A., Camargo F.A.O., 2011, Environmental Factors Affecting Chromium-Manganese OxidationReduction, Reactions in Soil, Pedosphere, vol. 21, no 1, p. 84-89.

51. Wang S., Vipulanandan C., 2000, Solidification/ stabilization of $\mathrm{Cr}(\mathrm{VI})$ with cement leachability and XRD analyses, Cement and Concrete Research, vol. 30, p. 385-389.

52. Widomski M.K., Gleń P., Łagód G., 2017, Sustainable Landfilling as Final Step of Municipal Waste Management System, Problemyekorozwoju problems of sustainable development, vol. 12, no 1, p. 147-155.

53. Wu J., Zhao L., Liu X.,Chen W.,Gu H., 2017, Recent progress in cleaner preservation of hides and skins, Journal of Cleaner Production, vol. 148, p. 158-173.

54. Zhang C., Lin J., Jia X., Peng B., 2016, A salt-free and chromium discharge minimizing tanning technology: the novel cleaner integrated chrome tanning process, Journal of Cleaner Production, vol. 112, p. 1055-1063.

55. Zouboulis A., Samaras P., Krestou A., Tzoupanos N., 2012, Leather production modification methods towards minimization of tanning pollution:green tanning, Fresenius Environmental Bulletin, vol. 21, p. $2406-2412$. 